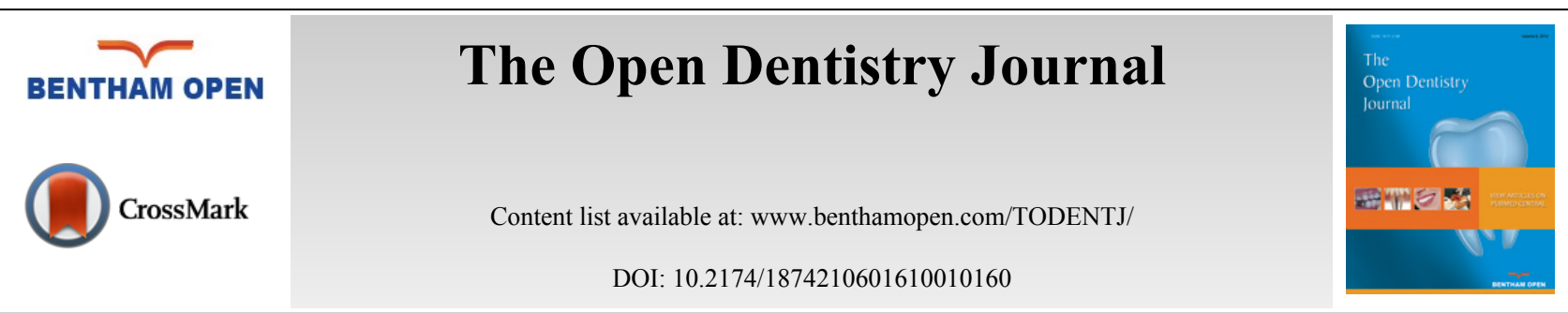

\title{
Evaluation of the Antibacterial Efficacy of Azadirachta Indica, Commiphora Myrrha, Glycyrrhiza Glabra Against Enterococcus Faecalis using Real Time PCR
}

Suresh Anand ${ }^{1, *}$, Mathan Rajan², Nagendrababu Venkateshbabu ${ }^{3}$, Deivanayagam Kandaswamy ${ }^{2}$, Yarramreddy Shravya ${ }^{2}$ and Kalaiselvam Rajeswari ${ }^{2}$

${ }^{I}$ Department of Conservative Dentistry and Endodontics, Penang International Dental College, Jalan Bagan Laur, 12000, Butterworth, Penang, Malaysia

${ }^{2}$ Department of Conservative Dentistry and Endodontics, Faculty of Dental Sciences, Sri Ramachandra University, Chennai, 600 116, India

${ }^{3}$ Department of Restorative Dentistry, School of Dentistry, International Medical University, Kuala Lumpur, Malaysia

Received: December 30, 2015

Revised: January 10, 2016

Accepted: January 28, 2016

\section{Abstract:}

Aim:

To compare the antibacterial efficacy of Azadirachta indica (Neem), Commiphora myrrha (Myrrh), Glycyrrhiza glabra (Liquorice) with $2 \%$ Chlorhexidine (CHX) against $E$. faecalis by using Real Time PCR

\section{Materials and Methods:}

A total of fifty teeth specimens $(\mathrm{n}=50)$ were inoculated with $E$. faecalis for 21 days. Specimens were divided into five groups (Group 1: Myrrh, Group 2: Neem, Group 3: Liquorice, Group 4: 2\% CHX and Group 5: Saline (negative control)). The intracanal medicaments were packed inside the tooth. After 5 days, the remaining microbial load was determined by using real time PCR

\section{Results:}

Threshold cycle $(\mathrm{Ct})$ values of Myrrh extract, Neem extract, Liquorice Extract, 2\% CHX and saline were found to be 30.94, 23.85, $21.38,30.93$ and 17.8 respectively

\section{Conclusion:}

Myrrh extract showed inhibition of E.faecalis equal to that of 2\% CHX followed by Neem, Liquorice and Saline

Keywords: Commiphora myrrha, Neem, Liquorice, $2 \%$ CHX, Dentinal tubules, intracanal medicament, real- time polymerase chain reaction.

\section{INTRODUCTION}

Elimination of bacteria is a critical step in root canal therapy since it is primarily responsible for periapical disease [1]. Bacterial elimination is usually attempted by mechanical instrumentation, irrigation and use of intracanal medicaments $[2,3]$. Irrigants like sodium hypocholorite $(\mathrm{NaOCl}), \mathrm{MTAD}$ and $2 \%$ Chlorhexidine $(\mathrm{CHX})$ are commonly

\footnotetext{
* Address correspondence to these authors at the Department of Conservative Dentistry and Endodontics, Penang International Dental College, Jalan Bagan Laur,12000, Butterworth, Penang, Malaysia; Tel : +919597853272; E-mail: andyendo@gmail.com
} 
used in root canal treatment [4]. Inspite of good efficacy of these irrigants, certain bacteria like Enterococcus faecalis might still survive inside the root canal system. E.faecalis plays a major role in persistent endodontic infections and is frequently isolated from failed root canal systems $[5,6]$. Intracanal medicaments help in the reduction of residual bacteria present after instrumentation and irrigation [7].

Natural herbal extracts have gained therapeutic importance in dental science in the recent days.Liquorice is a very sweet, moist, soothing herb which is most commonly used as a flavoring agent in kampo medicines. It has antiinflammatory [8] antiviral [9] and anticarcinogenic [10,11] properties.

Azadirachta indica, also known as "Indian neem" extensively used in Ayurveda, Unani and Homoeopathic medicine and has become a cynosure of modern medicine [12]. It has antibacterial [13, 14] antiviral [14] antifungal [15] antioxidant [16] anti-inflammatory [17] antimalarial properties [18]. Commiphora myrrha are small trees or shrubs with short, thorny branches, a variable species found in southern Arabia and northeast Africa (chiefly Somalia) as far south as northeast Kenya [19]. Myrrh is a known stimulant [20] analgesic [21] anti-inflammatory [22] antibacterial [23] antifungal [23] anticancer properties [24].

Hence, the aim of the present study was to evaluate the antibacterial efficacy of naturally available herbal extracts of Myrrh, Liquorice, Neem and compare it with that of 2\% CHX against E. faecalis, by using Real Time PCR.

\section{MATERIALS AND METHOD}

\section{Preparation of Herbal Extracts}

Herbal extract was obtained from the Faculty of Pharmacy, Sri Ramachandra University. Commiphora Myrrha, Neem leaves were shade dried, powdered and stored in air-tight containers. $1 \mathrm{~g}$ powder of Myrrh was dissolved in $10 \mathrm{ml}$ of sterilized distilled water. They were soaked at room temperature for 24 hours, then filtered [25]. Air dried Neem powder was repeatedly macerated with $500 \mathrm{ml}$ of $99 \%$ ethanol and filtered using whatman filter paper [26]. The ethanol was evaporated and the extracts were concentrated using rotary flash evaporator and stored at $4{ }^{\circ} \mathrm{C}$ until used in the assay [26]. Liquorice extract was prepared by the protocol mentioned in the reports of Badr et al [27].

\section{Determination of MIC of Natural Extracts}

Agar diffusion test was performed on Mueller-Hinton agar using the well diffusion method. Mueller-Hinton agar was freshly prepared after which, the surface was inoculated with $0.2 \mathrm{~mL}$ of brain heart infusion broth culture of $E$. faecalis strain ATCC 29212. The six wells ( $5 \mathrm{~mm}$ in diameter and $4 \mathrm{~mm}$ in depth) were created in the agar, of which three wells were filled with the plant extracts with 50\% ethanol as the solvent. Then, one well was filled with plain $50 \%$ ethanol without the extract which acted as the negative control. Further, two wells were filled with $2 \% \mathrm{CHX}$ and saline, respectively. The same procedure was carried out in duplicate and incubated for 24 hours anaerobically at $37^{\circ} \mathrm{C}$. Plates were read after 24 hours for the presence of zone of inhibition.

\section{Preparation of Dentin Specimens}

A total of fifty human mandibular premolars with single roots were used. Teeth with caries, apical fractures and resorption were excluded from the study. A rotary diamond disc was used to decoronate the teeth below the cemento enamel junction and the apical part of the root.Hence remaining portion of the root has been standardised (6mm). Cementum was removed from the root surface. The internal canal diameter was standardized by using Gates Glidden Drills No 4 (Mani Inc, Tachigiken, Japan). The debris was removed using ultrasonic bath of 17\% ethylene diamine tetra acetic acid for $5 \mathrm{~min}$, followed by $3 \% \mathrm{NaOCl}$ for $5 \mathrm{~min}$. The teeth were immersed in ultrasonic bath of distilled water for $10 \mathrm{~min}$. The specimens were autoclaved for $20 \mathrm{~min}$ at $121^{\circ} \mathrm{C}$.

\section{Antimicrobial Assessment}

A suspension of $50 \mu 1$ of E. faecalis (ATCC 29212) strain was incubated in 5ml of Trypticase Soy Agar broth (TSA) culture medium (Difco, Sparks, MD, USA) at $37^{\circ} \mathrm{C}$, anaerobically for 4 hours. The concentration of the inoculation was then adjusted for a degree of turbidity of 1, according to the McFarland scale. This corresponds to a bacterial load of $3 \times 10^{8}$ cells $/ \mathrm{ml}$ referent to an optical density of $550 \mathrm{~nm}$. The samples were recontaminated with fresh broth containing the E,faecalis every second day under laminar flow. The tooth specimen were removed from the broth, rinsed with sterile saline and dried . 
The blocks were divided into 5 groups ( $\mathrm{n}=10$ each): Group 1: Myrrh; Group 2: Neem; Group 3: Liquorice; Group 4: 2\% CHX and Group 5: saline (negative control). Methyl cellulose was used as the thickening agent for all the groups and the medicament was packed inside the root canal. The canals were then sealed at both the ends with paraffin wax and incubated at $37^{\circ} \mathrm{C}$ in an anerobic environment. After 5 days, the harvesting of dentin was carried out at $400 \mu \mathrm{m}$ depth with a sterile Gates-Gliden drill no. 5 [28].

\section{Bacterial Genomic DNA Isolation from Harvested Dentin}

To the dentin sample, $1 \mathrm{ml}$ of lysozyme stock solution was added and vortexed, which was then incubated at $37^{\circ} \mathrm{C}$ for 30 minutes. To this mixture, $10 \%$ sodium dodecylesulphate (SDS) was added and vortexed. The samples were again incubated at $37^{\circ} \mathrm{C}$ for $30 \mathrm{~min}$ in a water bath. Following the above step, equal volume of Phenol Chloroform was added and mixed by spinning at 10,000rpm for $10 \mathrm{~min}$. The supernatant was then transferred to new sterile Eppendorf tubes, to which an equal volume of Chloroform iso-amyl alcohol was added. Again, the supernatant was collected from this tube and transferred to a new Eppendorf tube, to which $1 / 10^{\text {th }}$ by volume sodium acetate and ethanol were added. Then, the solution was mixed by spinning at 10,000rpm for $10 \mathrm{~min}$ and the supernatant was discarded. The pellet was dried and to this $30 \mu \mathrm{l}$ of sterile water was added to dissolve the DNA, which was ready for the Real-time PCR analysis

\section{Real Time PCR - Detection of 16s rRNA Gene}

The Real Time PCR reaction was performed in a final volume of $20 \mu 1$ using a 96-well optical plate covered with an optical adhesive sheet. The Real-time PCR assay was carried out using thermal cycler (7900 HT Real-Time PCR system) with SYBR green .Universal 16s rRNA primers (forward primer 5'GATTAGATACCCTGGTAGTCC 3' and reverse primer 5' CCCGGGAACGTATTCACCG 3') for E. faecalis were used for quantification. The PCR conditions used were, $50^{\circ} \mathrm{C}$ for $2 \mathrm{~min}, 95^{\circ} \mathrm{C}$ for $10 \mathrm{~min}, 95^{\circ} \mathrm{C}$ for $15 \mathrm{~s}$, and $60^{\circ} \mathrm{C}$ for $1 \mathrm{~min}$ for 35 cycles. The efficacy of the treatment against $E$. faecalis was calculated based on the cycle threshold (CT) value [29, 30]

Table 1. Ct value (Mean \pm SD) for Myrrh, Neem, Liquorice, $2 \%$ CHX and saline.

\begin{tabular}{|c|c|}
\hline Groups (n=10 each) & Ct values (Mean \pm SD) \\
\hline Myrrh & $30.94 \pm 1.41$ \\
\hline Neem & $23.85 \pm 0.76$ \\
\hline Liquorice & $21.38 \pm 0.89$ \\
\hline $2 \%$ CHX & $30.93 \pm 1.58$ \\
\hline Saline & $17.8 \pm 0.31$ \\
\hline
\end{tabular}

${ }^{*} p<0.05$ was considered to be statistically significant.

Table 2. Percentage change in bacterial load.

\begin{tabular}{|c|l|}
\hline Groups (n= 10 each) & Percentage (\%) reduction in bacterial load in comparison to Saline \\
\hline Myrrh & 73.8 \\
\hline Neem & 33.9 \\
\hline Liquorice & 20.1 \\
\hline $2 \%$ CHX & 73.7 \\
\hline
\end{tabular}

\section{STATISTICAL ANALYSIS}

Data were statistically analysed using one-way ANOVA, followed by post hoc Tukey's HSD multiple comparison of means to compare the differences in bacterial inhibition between the groups. $p<0.05$ was considered to be statistically significant.

\section{RESULTS}

The minimum inhibitory concentration was determined to be $2.5 \mu \mathrm{g} / \mathrm{ml}, 4 \mu \mathrm{g} / \mathrm{ml}, 4 \mu \mathrm{g} / \mathrm{ml}, 2 \mu \mathrm{g} / \mathrm{ml}$ for Myrrh, Neem , Liquorice and 2\% CHX respectively. Polymerase chain reaction determines the result in threshold cycle $\left(\mathrm{C}_{\mathrm{T}}\right)$. The extracts in descending order of efficacy is as follows: Myrhh, 2\% CHX, Neem, Liquorice and saline (Table 1). Also, no statistically significant difference was observed seen between Myrrh and 2\% CHX. The percentage reduction of E faecalis after treatment with Myrhh, Neem, Liquorice, 2\% CHX was compared with saline (Table 2). 


\section{DISCUSSION}

The results of the present study showed that myrrh extract caused inhibition of E.faecalis equal to that of $2 \%$ CHX. This might be attributed to the anti-bacterial compounds sesquiterpene and T. cadinol present in Myrrh [31]. Sesquiterpene interacts with the cell envelopes which in turn leads to the disruption of cell membranes and thereafter, bacteriolysis [31].

In the present study, 2\% CHX was also shown to cause reduction of E.faecalis. Chlorhexidine is a bis-guanide that acts by adsorbing onto the cell wall of the microorganisms, causing changes in the outer cell membrane, resulting in leakage of intracellular components [32]. It is biocompatible and has broad-spectrum antimicrobial activity [33] targeting both the gram positive and gram-negative microbes [34].

Neem followed Myrrh extract and 2\% CHX in causing inhibition of bacterial growth. The antibacterial activity of neem could be due to the presence of several active constituents like nimbidin, nimbin, nimbolide, gedunin, azadirachtin, mahmoodin, margolone and cyclictrisulphide [35]. The respiratory chain is inhibited by these active constituents which inhibits the mitochondrial oxidative phosphorylation. The mitochondrial ATP content and intra mitochondrial levels of acetyl CoA, acid soluble COA and acid soluble CoA esters are also reduced [35].

The antimicrobial efficacy of Liquorice extract against E. faecalis, might be attributed to the Glycyrrhizin [36]. Unlike simply altering the surface tension of the extracellular medium, the antibacterial effects of saponins involve membranolytic properties [37]. Inhibition of oxygen consumption in bacterial cells is also due to the flavanoid content of the liquorice extract [38].

\section{CONCLUSION}

Myrrh extract had higher antibacterial efficacy compared to Neem and Liquorice. Further studies need to be conducted to ascertain the exact mechanisms of action of Myrrh extract against E. faecalis.

\section{CONFLICT OF INTEREST}

The authors confirm that this article content has no conflict of interest.

\section{ACKNOWLEDGEMENTS}

Declared none.

\section{REFERENCES}

[1] Möller ÃJ, Fabricius L, Dahlén G, Ohman AE, Heyden G. Influence on periapical tissues of indigenous oral bacteria and necrotic pulp tissue in monkeys. Scand J Dent Res 1981; 89(6): 475-84. [PMID: 6951246]

[2] Sathorn C, Parashos P, Messer H. Antibacterial efficacy of calcium hydroxide intracanal dressing: a systematic review and meta-analysis. Int Endod J 2007; 40(1): 2-10.

[http://dx.doi.org/10.1111/j.1365-2591.2006.01197.x] [PMID: 17209826]

[3] Matos Neto M, Santos SS, Leão MV, Habitante SM, Rodrigues JR, Jorge AO. Effectiveness of three instrumentation systems to remove Enterococcus faecalis from root canals. Int Endod J 2012; 45(5): 435-8. [http://dx.doi.org/10.1111/j.1365-2591.2011.01994.x] [PMID: 22211829]

[4] Kandaswamy D, Venkateshbabu N. Root canal irrigants. J Conserv Dent 2010; 13(4): 256-64. [http://dx.doi.org/10.4103/0972-0707.73378] [PMID: 21217955]

[5] Rôças IN, Siqueira JF Jr, Santos KR. Association of Enterococcus faecalis with different forms of periradicular diseases. J Endod 2004; 30(5): 315-20. [http://dx.doi.org/10.1097/00004770-200405000-00004] [PMID: 15107642]

[6] Stuart CH, Schwartz SA, Beeson TJ, Owatz CB. Enterococcus faecalis: its role in root canal treatment failure and current concepts in retreatment. J Endod 2006; 32(2): 93-8.

[http://dx.doi.org/10.1016/j.joen.2005.10.049] [PMID: 16427453]

[7] Siqueira JF Jr, Paiva SS, Rôças IN. Reduction in the cultivable bacterial populations in infected root canals by a chlorhexidine-based antimicrobial protocol. J Endod 2007; 33(5): 541-7. [http://dx.doi.org/10.1016/j.joen.2007.01.008] [PMID: 17437868]

[8] Bodet C, La VD, Gafner S, Bergeron C, Grenier D. A licorice extract reduces lipopolysaccharide-induced proinflammatory cytokine secretion by macrophages and whole blood. J Periodontol 2008; 79(9): 1752-61. [http://dx.doi.org/10.1902/jop.2008.080052] [PMID: 18771378] 
[9] Bean P. The use of alternative medicine in the treatment of hepatitis C. Am Clin Lab 2002; 21(4): 19-21. [PMID: 12087634]

[10] Lee CK, Park KK, Lim SS, Park JH, Chung WY. Effects of the licorice extract against tumor growth and cisplatin-induced toxicity in a mouse xenograft model of colon cancer. Biol Pharm Bull 2007; 30(11): 2191-5. [http://dx.doi.org/10.1248/bpb.30.2191] [PMID: 17978499]

[11] Lee S, Oh H-M, Lim W-B, et al. Gene induction by glycyrol to apoptosis through endonuclease G in tumor cells and prediction of oncogene function by microarray analysis. Anticancer Drugs 2008; 19(5): 503-15. [http://dx.doi.org/10.1097/CAD.0b013e3282fba582] [PMID: 18418217]

[12] Subapriya R, Nagini S. Medicinal properties of neem leaves: a review. Curr Med Chem Anticancer Agents 2005; 5(2): 149-6. [http://dx.doi.org/10.2174/1568011053174828] [PMID: 15777222]

[13] Rao DS, Penmatsa T, Kumar AK, Reddy MN, Gautam NS, Gautam NR. Antibacterial activity of aqueous extracts of Indian chewing sticks on dental plaque: An in vitro study. J Pharm Bioallied Sci 2014; 6(1)(Suppl. 1): S140-5. [PMID: 25210357]

[14] Bharitkar YP, Bathini S, Ojha D, et al. Antibacterial and antiviral evaluation of sulfonoquinovosyldiacylglyceride: a glycolipid isolated from Azadirachta indica leaves. Lett Appl Microbiol 2014; 58(2): 184-9. [http://dx.doi.org/10.1111/lam.12174] [PMID: 24118020]

[15] Mahilrajan S, Nandakumar J, Kailayalingam R, Manoharan NA. SriVijeindran S. Screening the antifungal activity of essential oils against decay fungi from palmyrah leaf handicrafts. Biologic Res 2014; 47: 35. [http://dx.doi.org/10.1186/0717-6287-47-35]

[16] Rao A, Devi K, Thyagaraju K. Ayurtox for body Detoxification. Enz Inhib 1998; 14: 85-6. [http://dx.doi.org/10.3109/14756369809036547]

[17] Tidjani M, Dupont C, Wepierre J. Antiinflammatory activity of Azadirachta indica. Planta Med Phytothe 1989; 23: 259-66.

[18] Dhar R, Zhang K, Talwar GP, Garg S, Kumar N. Inhibition of the growth and development of asexual and sexual stages of drug-sensitive and resistant strains of the human malaria parasite Plasmodium falciparum by Neem (Azadirachta indica) fractions. J Ethnopharmacol 1998; 61(1): 31-9.

[http://dx.doi.org/10.1016/S0378-8741(98)00012-9] [PMID: 9687079]

[19] Hanuš LO, Řezanka T, Dembitsky VM, Moussaieff A. Myrrh-Commiphora chemistry. Biomed Pap Med Fac Univ Palacky Olomouc Czech Repub 2005; 149(1): 3-27.

[http://dx.doi.org/10.5507/bp.2005.001] [PMID: 16170385]

[20] Tipton DA, Hamman NR, Dabbous MKh. Effect of myrrh oil on IL-1beta stimulation of NF-kappaB activation and PGE(2) production in human gingival fibroblasts and epithelial cells. Toxicol In Vitro 2006; 20(2): 248-55. [http://dx.doi.org/10.1016/j.tiv.2005.07.004] [PMID: 16112536]

[21] Dolara P, Luceri C, Ghelardini C, et al. Analgesic effects of myrrh. Nature 1996; 379(6560): 29. [http://dx.doi.org/10.1038/379029a0] [PMID: 8538737]

[22] Su S, Wang T, Duan J-A, et al. Anti-inflammatory and analgesic activity of different extracts of Commiphora myrrha. J Ethnopharmacol $2011 ; 134(2): 251-8$. [http://dx.doi.org/10.1016/j.jep.2010.12.003] [PMID: 21167270]

[23] Dolara P, Corte B, Ghelardini C, et al. Local anaesthetic, antibacterial and antifungal properties of sesquiterpenes from myrrh. Planta Med 2000; 66(4): 356-8. [http://dx.doi.org/10.1055/s-2000-8532] [PMID: 10865454]

[24] Shoemaker M, Hamilton B, Dairkee SH, Cohen I, Campbell MJ. In vitro anticancer activity of twelve Chinese medicinal herbs. Phytother Res 2005; 19(7): 649-51.

[http://dx.doi.org/10.1002/ptr.1702] [PMID: 16161030]

[25] Boyraz N, Ozcan M. Antifungal effect of some spice hydrosols. Fitoterapia 2005; 76(7-8): 661-5. [http://dx.doi.org/10.1016/j.fitote.2005.08.016] [PMID: 16243447]

[26] Vinothkumar TS, Rubin MI, Balaji L, Kandaswamy D. In vitro evaluation of five different herbal extracts as an antimicrobial endodontic irrigant using real time quantitative polymerase chain reaction. J Conserv Dent 2013; 16(2): 167-70. [http://dx.doi.org/10.4103/0972-0707.108208] [PMID: 23716972]

[27] Badr AE, Omar N, Badria FA. A laboratory evaluation of the antibacterial and cytotoxic effect of Liquorice when used as root canal medicament. Int Endod J 2011; 44(1): 51-8. [http://dx.doi.org/10.1111/j.1365-2591.2010.01794.x] [PMID: 20812941]

[28] Kandaswamy D, Venkateshbabu N, Gogulnath D, Kindo AJ. Dentinal tubule disinfection with 2\% chlorhexidine gel, propolis, morinda citrifolia juice, $2 \%$ povidone iodine, and calcium hydroxide. Int Endod J 2010; 43(5): 419-23. [http://dx.doi.org/10.1111/j.1365-2591.2010.01696.x] [PMID: 20518935]

[29] Endo MS, Ferraz CC, Zaia AA, Almeida JF, Gomes BP. Quantitative and qualitative analysis of microorganisms in root-filled teeth with persistent infection: Monitoring of the endodontic retreatment. Eur J Dent 2013; 7(3): 302-9. [http://dx.doi.org/10.4103/1305-7456.115414] [PMID: 24926210] 
[30] Winfred SB, Meiyazagan G, Panda JJ, et al. Antimicrobial activity of cationic peptides in endodontic procedures. Eur J Dent 2014; 8(2): 254-60. [http://dx.doi.org/10.4103/1305-7456.130626] [PMID: 24966779]

[31] Claeson P, Rådström P, Sköld O. Nilsson Ãs, Höglund S. Bactericidal effect of the sesquiterpene T-cadinol on Staphylococcus aureus. Phytother Res 1992; 6(2): 94-8. [http://dx.doi.org/10.1002/ptr.2650060209]

[32] Carlo Ceschel G, Bergamante V, Calabrese V, Biserni S, Ronchi C, Fini A. Design and evaluation in vitro of controlled release mucoadhesive tablets containing chlorhexidine. Drug Dev Ind Pharm 2006; 32(1): 53-61. [http://dx.doi.org/10.1080/03639040500388300] [PMID: 16455604]

[33] Delany GM, Patterson SS, Miller CH, Newton CW. The effect of chlorhexidine gluconate irrigation on the root canal flora of freshly extracted necrotic teeth. Oral Surg Oral Med Oral Pathol 1982; 53(5): 518-23. [http://dx.doi.org/10.1016/0030-4220(82)90469-8] [PMID: 6954427]

[34] Yesilsoy C, Whitaker E, Cleveland D, Phillips E, Trope M. Antimicrobial and toxic effects of established and potential root canal irrigants. J Endod 1995; 21(10): 513-5. [http://dx.doi.org/10.1016/S0099-2399(06)80524-8] [PMID: 8596073]

[35] Bandyopadhyay U, Biswas K, Chattopadhyay I, Banerjee R. Biological activities and medicinal properties of neem (Azadirachta Indica). Curr Sci 2002; 82: 1336-45.

[36] Badria F, Houssen W, El-Nashar E, Said S. Biochemical and histopathological evaluation of Glycyrrhizin and Boswellia carterii extract on rat liver injury. Biosci Biotechnol Res Asia 2003; 1(2): 93-6.

[37] Avato P, Bucci R, Tava A, et al. Antimicrobial activity of saponins from Medicago sp.: structure-activity relationship. Phytother Res 2006; 20(6): 454-7. [http://dx.doi.org/10.1002/ptr.1876] [PMID: 16619355]

[38] Haraguchi H, Tanimoto K, Tamura Y, Mizutani K, Kinoshita T. Mode of antibacterial action of retrochalcones from Glycyrrhiza inflata. Phytochemistry 1998; 48(1): 125-9.

[http://dx.doi.org/10.1016/S0031-9422(97)01105-9] [PMID: 9621457]

(C) Anand et al. ; Licensee Bentham Open.

This is an open access article licensed under the terms of the Creative Commons Attribution-Non-Commercial 4.0 International Public License (CC BY-NC 4.0) (https://creativecommons.org/licenses/by-nc/4.0/legalcode), which permits unrestricted, non-commercial use, distribution and reproduction in any medium, provided the work is properly cited. 